\title{
MicroRNAs in gastrointestinal cancer: a novel biomarker and its clinical application
}

\author{
Yukiharu Hiyoshi, Masayuki Watanabe \\ Department of Gastroenterological Surgery, Cancer Institute Hospital of Japanese Foundation for Cancer Research, Tokyo 135-8550, Japan.
}

Correspondence to: Dr. Masayuki Watanabe, Department of Gastroenterological Surgery, Esophageal Cancer Division, Cancer Institute Hospital of Japanese Foundation for Cancer Research, 3-8-31 Ariake, Koto-Ku, Tokyo 135-8550 Japan. E-mail: masayuki.watanabe@jfcr.or.jp

\section{A B S T R A C T}

Gastrointestinal (GI) cancers remain one of the most common malignancies and are the major cause of cancer deaths worldwide. Significant advancements have improved our understanding of the pathogenesis and pathology of GI cancers, but high mortality rates, an unfavorable prognosis, and lack of clinical predictive biomarkers provide an impetus to investigate novel diagnostic/prognostic markers and therapeutic targets for GI cancers. MicroRNAs (miRNAs) are short (19-24 nucleotides), non-coding RNA molecules that regulate gene expression at the post-transcriptional level, thus playing an important role in modulating various biological processes. This includes developmental processes, proliferation, apoptosis, metabolism and differentiation, all involved in initiation and progression of various human cancers. Aberrant miRNA expression profiles have been observed in various cancer types at different stages, suggesting their potential as diagnostic and prognostic biomarkers. Due to their tumor- and tissue-specific expression profiles, stability, and the availability of robust clinical assays for their detection in serum as well as in formalin-fixed tissue samples, miRNAs have emerged as attractive candidates for diagnostic and prognostic applications. This review summarizes recent research supporting the utility of miRNAs as novel diagnostic/prognostic tools and therapeutic targets, thus potentially illuminating future treatment strategies for GI cancers.

Key words: Biomarker, gastrointestinal cancer, microRNA, therapeutic target

\section{Introduction}

Gastrointestinal (GI) cancers represent malignant tumors of the GI tract and accessory organs of digestion including esophagus, stomach, liver, biliary tract, pancreas, small intestine, large intestine and rectum. GI cancers are collectively the major cause of cancer-related to morbidity and mortality worldwide ${ }^{[1]}$ Current multimodal treatment strategies including surgery, radiotherapy, and/or chemotherapy have marginally improved curative expectations and quality of life of patients; however, the effectiveness of these new tools depends largely on the stage in which tumors are detected. Previous investigators have tried to identify more specific and sensitive novel biomarkers and therapeutic targets for better diagnosis and management of lethal GI cancers.

MicroRNAs (miRNAs) are short, non-coding RNA molecules of approximately 19-24 nucleotides involved in post-transcriptional regulation of gene expression. miRNAs bind to the 3'-untranslated region of mRNA, leading to either translational repression or

\section{Access this article online}

Quick Response Code:

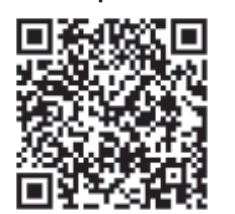

Website:

www.jcmtjournal.com

DOI:

$10.4103 / 2394-4722.161617$
mRNA degradation initiated by miRNA-guided rapid deadenylation. ${ }^{[2]}$ It has been estimated that $60 \%$ of human protein coding genes are subject to regulation by miRNAs. ${ }^{[3]}$ They act as master regulators for many important biological processes including ontogeny, cell proliferation, apoptosis, migration, differentiation, metabolism, stress, viral infection, cancer initiation and progression and drug resistance. ${ }^{[4-7]}$ In addition, several miRNAs may also be useful for diagnostic, prognostic and therapeutic applications in GI cancers. ${ }^{[8-12]}$

Numerous investigations on screening for altered expression of miRNAs in various types of cancer have been conducted during the past decade, with more and more functional validations in recent years. Although the majority of such studies have so far focused on miRNA profiling to identify specific miRNA species and determining their role in the biology of GI cancers, another great potential for miRNA profiling lies in their

This is an open access article distributed under the terms of the Creative Commons Attribution-NonCommercial-ShareAlike 3.0 License, which allows others to remix, tweak, and build upon the work non-commercially, as long as the author is credited and the new creations are licensed under the identical terms.

For reprints contact: reprints@medknow.com

How to cite this article: Hiyoshi Y, Watanabe M. MicroRNAs in gastrointestinal cancer: a novel biomarker and its clinical application. J Cancer Metastasis Treat 2015;1:144-55.

Received: 07-06-2015; Accepted: 29-06-2015. 
use as biomarkers, either in diagnosis or in prediction/ monitoring of therapeutic responses. This review focuses on the most recent advances in studies on some extensively investigated miRNAs in GI cancers, particularly with regard to their potential as novel biomarkers or therapeutic targets.

\section{Esophageal Cancer}

The incidence and mortality of esophageal cancer (EC) are high, ranking eighth and sixth respectively, all types of cancer, affecting more males than females. ${ }^{[13]}$ Esophageal squamous cell carcinoma (ESCC) and esophageal adenocarcinoma (EAC) are the two main EC subtypes. Due to the potential characteristics of invasion and metastasis in esophageal carcinoma cells, the overall 5-year survival rate is poor despite advanced treatment. ${ }^{[13,14]}$ Recent discoveries have shed new light on the involvement of miRNA in EC. ${ }^{[15]}$

\section{miRNAs as novel diagnostic and prognostic biomarkers in EC}

Guo et al. ${ }^{[16]}$ found aberrant expression of 46 miRNAs in EC tissues, of which 7 miRNAs may be used as biomarkers to distinguish malignant EC lesions from adjacent normal tissue. Moreover, miR-335, miR-181d, miR-25, miR-7 and miR-495 are associated with the pathological type of EC (fungating $v s$. medullary). miR-25 and miR-130b are associated with the degree of differentiation of EC and miR-103/107 expression level negatively correlated with survival rates miR-25 and miR-130b may also be used for early diagnosis as well as gene therapy targets for EC. Feber et al. ${ }^{[17]}$ found that miR-203 and miR-205 were down-regulated compared with normal epithelium in EC, while miR-21 was overexpressed in the two types of EC. miR-200c, miR-194 and miR-192 were up-regulated in EAC. Mathe et al. ${ }^{[18]}$ have demonstrated that the overexpression of miR-21 in non-cancerous tissue of ESCC and down-regulation of miR-375 in cancerous tissue of EAC with Barrett's esophagus (BE) were markedly associated with a worse prognosis. miR-196a was highly expressed in EAC, BE, benign and malignant junctions and highly malignant tissue and thus be used as a biomarker for screening EC. ${ }^{[18-20]}$ Among others, the overexpression of miR-129 was identified as a significant and independent prognostic factor in surgically treated ESCC patients. ${ }^{[21]}$ The expression level of miR-1322 was higher in ESCC tissue, making it possible to distinguish ESCC from healthy samples. ${ }^{[22]}$ Expressions of miR-31 and miR-142-3p correlated with histological differentiation, with high miR-142-3p expression being associated with poor prognosis. Therefore, this may be a potential independent prognostic ESCC factor. ${ }^{[23]}$ Furthermore, expression profiles of miRNAs have been found to be altered in progressive stages of EC neoplastic development, with expression levels of miR-31 and $\mathrm{miR}-31^{*}$ being frequently down-regulated in EAC. ${ }^{[24]}$
Other significant miRNAs with dysregulated expression are miR-16-2 and miR-30e, which were associated with a shorter overall and disease-free survival in all EC patients. ${ }^{[25]}$

Several studies have demonstrated that miRNAs are consistently detectable in the circulation. The expression level of miR-21 was up-regulated and miR-375 was down-regulated in plasma of ESCC patients compared with healthy controls; patients with high plasma levels of miR-21 had greater vascular invasion and showed high correlation with recurrence. ${ }^{[26]}$ A panel of 7 serum miRNAs (miR-10a, miR-22, miR-100, miR-148b, miR-223, miR-133a and miR-127-3p) was up-regulated in ESCC and could clearly distinguish stage I/II ESCC patients from controls. ${ }^{[27]}$ Supporting the role of miRNAs in the circulation, Zhang et al. ${ }^{[28]}$ have found that miR-31 levels were significantly higher than controls in 523 serum ESCC samples. In addition, patients with higher levels of serum miR-31 had a poorer prognosis for relapse-free survival. miR-1322 was significantly highly expressed in ESCC serum and could be used to distinguish ESCC from healthy patients. ${ }^{[22]}$ Thus, circulating miRNAs may be used as potential biomarkers, not only for diagnostic, but also for prognostic and predictive markers in EC.

\section{Clinical application of microRNAs in EC}

Hummel et al. ${ }^{[29]}$ examined the impact of chemotherapy on miRNA expression in EC cells and found that 13 miRNAs were deregulated following treatment with cisplatin or 5-fluorouracil (5FU). miR-141 was most highly expressed in the cisplatin-resistant ESCC cell lines, the target of miR-141 is YAP1, which is an apoptosis-inducing gene in DNA-damaging agents. ${ }^{[30]}$ miR-296 and miR-27a are overexpressed in EC, and knockdown of miR-296 and miR-27a was found to be capable of increasing sensitivity to both P-glycoprotein-related and P-glycoprotein-non-related drugs, in turn promoting ADR-induced apoptosis in EC cells. ${ }^{[31,32]}$ Overexpression of miR-200c significantly correlated with response to chemotherapy, with this effect being associated with the Akt pathway. ${ }^{[33]}$ miR-148a up-regulation significantly increased the sensitivity to chemotherapy in the majority of cells. ${ }^{[34]} \mathrm{miR}-200 \mathrm{~b} / 200 \mathrm{c} / 429$ were up-regulated in endometrial cancer and EC, and their overexpression correlated with resistance to cisplatin treatment. ${ }^{[35]}$

\section{Gastric Cancer}

Gastric cancer (GC) is the second leading cause of cancer-related death worldwide. Approximately one million new GC cases per year were estimated to have occurred in 2010. ${ }^{[36]}$ Helicobacter pylori infection, Epstein-Barr virus infection, gastrin levels, germline mutations, dietary factors, and other chronic gastric conditions are all factors felt to be involved in GC development. GC is often diagnosed at an advanced 
stage, accompanied by extensive invasion and lymphatic metastasis. ${ }^{[37]}$ Thus, it is important to increase the sensitivity and specificity of diagnostic markers and/or to establish methods for GC treatment and prevention of GC. ${ }^{[38-40]}$

\section{miRNAs as novel diagnostic and prognostic biomarkers in GC}

Novel methods, such as circulating miRNA profiling, have been suggested to be useful tools for the non-invasive diagnosis of GC. Three serum miRNAs (miRs-221/744/376c) were found to distinguish GC patients from healthy controls with $82.4 \%$ sensitivity and $58.8 \%$ specificity. ${ }^{[1]}$ Moreover, miR-221 and miR-376c demonstrated significantly positive correlations with poor GC differentiation. ${ }^{[41]}$ In a validation experiment, plasma levels of miR-451 and miR-486 were higher in patients with GC compared with healthy controls, with high area under the curve (AUC) values (0.96 and 0.92). ${ }^{[42]}$ A genome-wide miRNA profile identified high serum levels of miR-378 in patients with GC, and validation yielded a high AUC (0.86). ${ }^{[43]}$ Quantitative real-time polymerase chain reaction analysis identified 5 serum miRNAs (miR-1, miR-20a, miR-27a, miR-34, miR-423-5p) to be biomarkers for $\mathrm{GC}$, and their levels correlated with tumor stage. ${ }^{[4]}$ Plasma concentrations of miRNAs miR-17-5p, miR-21, miR-106a and miR-106b were higher, whereas let-7a was lower in GC patients. AUC as high as 0.879 for the miR-106a/let-7a ratio assay was achieved. ${ }^{[45]}$ High levels of miR-17 and miR-106a in peripheral blood of GC patients confirmed in another study, in which the AUC value for the combined miR-17/miR-106a assay was $0.741 .{ }^{[46]}$ These findings suggest that miRNAs are useful biomarkers for early GC diagnosis.

miRNAs have recently been used to predict the outcome of patients with GC. For example, a seven-miRNA signature (miR-10b, miR-21, miR-223, miR-338, let-7a, miR-30a-5p and miR-126) was shown to be closely associated with relapse-free and overall survival (OS) among patients with GC. ${ }^{[47]}$ High expression of miR-20b, miR-150 ${ }^{[48]}$ and miR-93 ${ }^{[49]}$ or down-regulation of miR-451 $1^{[50]}$ or miR-218 $8^{[51]}$ was also associated with poor survival, whereas there was a correlation between miR-27a and lymph node metastasis. ${ }^{[48]}$ In addition, Ueda et $a l .{ }^{[52]}$ recently reported that miR-125b, miR-199a and miR-100 represent a progression-related signature, whereas the low expression of let-7g and high expression of miR-214 were associated with shorter OS independent of the depth of invasion, lymph node metastasis and stage.

Circulating miRNAs have been suggested to be useful prognostic markers of GC. High expression of circulating miR-17-5p/20a was an independent poor prognostic factor. ${ }^{[53]}$ Low-level expression of let- $7 \mathrm{a} /$ let-7g/let-7f was associated with a poor prognosis. ${ }^{[54,55]}$
miR-181b and miR-182 were also found to be novel poor prognosticators. ${ }^{[56]}$ Low expression of miR-125a-3p was associated with enhanced malignant potential, such as tumor size, lymph node, and liver metastasis, and poor prognosis, and this study suggested that miR-125a-3p is a potent prognostic marker in GC. ${ }^{[57]}$ Furthermore, miR-409-3p was found to be frequently down-regulated in patients with $\mathrm{GC}$, and its expression was associated with distant metastasis. ${ }^{[58]}$

\section{Clinical application of miRNAs in GC}

Some miRNAs have been shown to impact chemotherapy sensitivity if their levels were artificially up-regulated, others if they were down-regulated. For instance, up-regulation of miR-21 or miR-106a increased cisplatin resistance of GC cells, ${ }^{[59]}$ and Deng et $a l .{ }^{[60]}$ showed that the up-regulation of miR-195 or miR-378 led to enhanced 5-azacytidine resistance in normal gastric cells. Up-regulation of miR-449 or miR-508-5p was demonstrated to positively impact sensitivity toward cisplatin (miR-449) or vincristine or doxorubicin (miR-508-5p). ${ }^{[1,62]}$ Interestingly, in accordance with these findings concerning the modulation of the sensitivity toward chemotherapeutic drugs via miRNAs, Bandres et al. ${ }^{[50]}$ reported that the up-regulation of miR-451 led to increased sensitivity of cancer cells toward radiotherapy by down-regulating macrophage migration inhibitory factor MIF. Only one research group reported the effect of miRNA down-regulation on chemotherapy resistance; Zhao et al. ${ }^{[63]}$ found that increased doxorubicin sensitivity in GC cells was connected with down-regulation of miR-27a.

\section{Colorectal Cancer}

Colorectal cancer (CRC) is the 3rd most common cancer and the 3rd leading cause of cancer-related death in the world, with an estimated incidence of one million new cases and a mortality of $>500,000$ deaths annually. ${ }^{[13]}$ The pathogenesis of CRC typically follows a protracted stepwise progression from benign adenoma to malignant adenocarcinoma and distant metastasis, rendering screening and early diagnosis as preferred options to ease the disease burden. ${ }^{[64]}$ This also highlights the need for the development of novel screening tools and diagnostic biomarkers.

\section{miRNAs as novel diagnostic and prognostic biomarkers in CRC}

$\mathrm{Ng}$ et $a l{ }^{[65]}$ were the first to report that circulating levels of miRNAs differed in the blood plasma in CRC cases and the controls. It was found that miR-92 was expressed at higher levels in the plasma from CRC cases and could distinguish cases from healthy control patients with $70 \%$ specificity and $89 \%$ sensitivity. Another study of 120 cases and 29 controls validated these findings, showing that levels of miR-92 can discriminate between CRC cases and controls with $65 \%$ sensitivity and $82 \%$ specificity. ${ }^{[66]}$ 
A similar study found that levels of miR-141 were elevated in metastatic CRC and its expression was associated with a poor prognosis, suggesting that this miRNA may be used in conjunction with carcinoembryonic antigen to detect CRC with distant metastases. ${ }^{[67]}$

Measuring miRNAs in stool offers another non-invasive approach to detect CRC. One small study of 29 CRC cases and 8 healthy controls found that stool from CRC cases expressed higher levels of miR-21 and miR-106a. ${ }^{[68]}$ A larger study of 197 cases and 134 healthy controls investigated miRNA expression patterns of colonocytes isolated from feces and was able to demonstrate that miRNA expression patterns could distinguish cases from controls with $74 \%$ sensitivity and $79 \%$ specificity. ${ }^{[69]}$ A similar strategy found that miRNA methylation patterns from DNA isolated from stool may be promising as a screening tool for CRC. ${ }^{[70]}$ The hypermethylation pattern of miR-34b/c in stool samples could distinguish CRC cases from controls with $75 \%$ sensitivity and $84 \%$ specificity. Further tests are warranted to determine whether miRNA expression or methylation patterns in stool can be utilized, either alone or in combination with a fecal occult blood test, as an effective screening strategy for CRC.

The elevated expression of miR-21 has a robust and reproducible association with the CRC prognosis. Schetter et al. ${ }^{[71]}$ first reported that elevated miR-21 expression in tumors was associated with a worse survival prognosis and therapeutic outcome. The association of elevated miR-21 expression and worse survival outcomes in CRC has been validated in at least three additional studies. These include the studies of 156 Japanese CRC patients, ${ }^{[72]} 46 \mathrm{CRC}$ patients from the Czech Republic, ${ }^{[73]}$ and 130 tumor node metastasis stage II colon cancer patients from Denmark. ${ }^{[74]}$ Additional studies have identified miRNA expression patterns that are associated with either prognosis or therapeutic outcome. Expression levels of miR-106b, ${ }^{[75]}$ miR-320, ${ }^{[76]}$ miR-498, ${ }^{[76]}$ miR-125b, ${ }^{[77]} \operatorname{miR}-145,{ }^{[78]}$ miR-185, ${ }^{[79]} \operatorname{miR}-133 b,{ }^{[79]}$ miR-215 $5^{[80]}$ and $\mathrm{miR}-17^{[81]}$ have each been reported to be associated with prognosis or therapeutic outcome. An elevated expression of Dicer, an important gene encoding an RNA nuclease involved in miRNA processing, is associated with poor prognosis in CRC. ${ }^{[82]}$ Further validation of these associations is warranted and may reveal additional prognostic classifiers.

\section{Clinical application of miRNAs in CRC}

Schetter et al. ${ }^{[71]}$ have shown that miR-21 expression is associated with therapeutic outcome with 5FU-based therapies. This association, in combination with the known oncogenic role for miR-21, suggests that increased miR-21 expression is, in part, responsible for resistance to 5FU. Elevated miR-21 induces resistance to $5 \mathrm{FU}$ in colon cancer cell lines by down-regulating DNA repair protein MutS homolog 2. ${ }^{[83]}$ Exposure of colon cancer cells to 5FU leads to increased miR-21 expression, and this may be a response to genotoxic stress to help cells overcome the effects of 5FU. ${ }^{[84]}$ Additional in vitro data support the roles for altered expression of miR-140, ${ }^{[85]}$ miR-215, ${ }^{[86]} \mathrm{miR}-224^{[87]}$ and miR-20a ${ }^{[88]}$ in developing chemoresistance. Further studies are warranted to determine whether expression of these miRNAs can predict response to chemotherapy and if those miRNAs can be used as therapeutic targets themselves. MiRNA replacement involves reintroducing synthetic miRNA mimics or expression vectors that will produce the miRNA of interest. This has shown promise in preclinical murine models where the reintroduction of miR-145 and miR-33a had an antitumor effect in a model of colon cancer. ${ }^{[89]}$

\section{Hepatocellular Carcinoma}

Hepatocellular carcinoma (HCC), the most common primary liver cancer, is the 5 th most frequent cancer and the third cause of cancer-related mortality worldwide. ${ }^{[90]}$ The incidence of this disease is $>600,000$ cases annually. ${ }^{[91,92]}$ HCC usually develops as a consequence of underlying liver disease and is often associated with cirrhosis. ${ }^{[93]}$ Hepatitis B virus (HBV) and hepatitis $\mathrm{C}$ virus (HCV) viral infections, the major risk factors for $\mathrm{HCC}$ development, lead to liver cirrhosis and account for $75 \%$ of HCC cases. ${ }^{[94,95]}$ miRNAs have been widely reported to be involved in HCC development and may be new targets for HCC therapy. ${ }^{[96-98]}$

\section{miRNAs as novel diagnostic and prognostic biomarkers in $\mathrm{HCC}$}

Many miRNAs are dysregulated in HCC; thus, it is to be expected that circulating miRNA levels are also affected by HCC progression. The high stability of miRNAs in circulation makes them excellent biomarkers, especially for early detection. ${ }^{[99]}$ It is interesting that circulating miR-21, ${ }^{[100,101]} \mathrm{miR}-222^{[101]}$ and $\mathrm{miR}-223,{ }^{[102]}$ were up-regulated in serum/plasma of HCC patients associated with HBV or HCV. Circulating miR-21 levels were significantly higher in HCC patients than in those with chronic hepatitis and healthy controls. A receiver-operating characteristic analysis of miR-21 yielded an AUC of 0.773 when differentiating HCC from chronic hepatitis, and an AUC of 0.953 when differentiating HCC from healthy controls. Both sets of values were superior to alpha-fetoprotein (AFP) as an HCC biomarker. ${ }^{[102]}$ At the same time, the serum levels of miR-1, miR-25, miR-92a, miR-206, miR-375 and let-7f were also significantly elevated. ${ }^{[103]}$

Serum miR-15b and miR-130b levels were also up-regulated in HCC. ${ }^{[104]}$ MiR-130b had the largest AUC (0.913), with a sensitivity of $87.7 \%$ and specificity of $81.4 \%$, and miR-15b had the highest sensitivity of miRNAs examined (98.3\%), although its specificity was very low $(15.3 \%)$. The high sensitivity of circulating 
miR-15b and miR-130b as biomarkers holds promise for patients with early-stage HCC, who may have low AFP levels despite the presence of disease. Similarly, serum miR-16 was found to be a more sensitive biomarker than serum AFP and Des- $\gamma$-carboxyprothrombin (DCP). ${ }^{[105]}$ The combination of miR-16, AFP, AFP-L3\%, and DCP yielded the optimal combination of sensitivity (92.4\%) and specificity $(78.5 \%)$ for HCC overall and when the analysis was restricted to patients with tumors smaller than $3 \mathrm{~cm} \cdot{ }^{[106]}$ In addition, a recent meta-analysis of 8 studies showed the diagnostic value of miRNAs as follows: Pooled sensitivity 0.87 (0.72-0.98), pooled specificity $0.90(0.76-1.00)$, pooled positive likelihood ratio $8.7(3.52-97.45)$, pooled negative likelihood ratio $0.13(0.02-0.31)$, and pooled diagnostic odds ratio $86.69(19.06-2646.00) \cdot{ }^{[107]}$

Although sensitivity and stability of miRNAs as biomarkers are suitable for a clinical setting, appropriate controls must be used in a research setting because HCC is often accompanied by viral hepatitis, cirrhosis, or other underlying liver conditions. ${ }^{[108]}$ When assessing the specificity of an miRNA for detecting HCC, it is critical to ensure that patients and controls are matched, not only by age and sex, but also by etiology and severity of the underlying liver disease.

\section{Clinical application of miRNAs in HCC}

Recently, miravirsen, a locked nucleic acid-modified DNA phosphorothioate antisense oligonucleotide against miR-122, became the first miRNA-targeting drug to receive permission for clinical use. ${ }^{[109]}$ It was developed to target $\mathrm{HCV}$, as the stability and propagation of this virus are dependent on a functional interaction between the HCV genome and miR-122. ${ }^{[110,111]}$ Miravirsen resulted in a dose-dependent reduction in $\mathrm{HCV}$ levels, without major adverse events and with no escape mutations in miR-122 binding sites of the $\mathrm{HCV}$ genome. ${ }^{[109]}$ The success of miravirsen is promising, not only as a novel anti-HCV drug, but also as the first trial of miRNA-targeting therapy. In addition to miravirsen, a clinical trial of MRX34 (miRNA Therapeutics, Austin, TX, USA) as a mimic of miR-34 is underway. MRX34 is a liposome-formulated mimic of the tumor suppressor, miR-34. Further study of MRX34 is being conducted by miRNA Therapeutics, which initiated a Phase I study in May 2013 to examine effects of MRX34 on unresectable primary liver cancer or advanced or metastatic cancer with liver involvement. If these oligonucleotide therapies are successful, then therapeutic options based on the numerous miRNAs deregulated during hepatocarcinogenesis appear to be promising. ${ }^{[112]}$

\section{Cholangiocarcinoma}

Cholangiocarcinoma (CCA) is one of the most common malignancies derived from bile duct epithelial cells. ${ }^{[113]}$ Due to slow growth, late metastasis, and lack of effective screening methods, CCA is rarely diagnosed during early stages of the disease when surgical procedures are most effective. ${ }^{[114]}$ Histopathological analyses suggest that the presence of primary sclerosing cholangitis, chronic biliary irritation, or choledochal cysts may predispose individuals to $\mathrm{CCA}^{[115]}$ More recently, studies have identified a role for miRNAs in the development of CCA by altering different cholangiocyte features such as cell cycle, proliferation, migration and apoptosis. ${ }^{[116-118]}$

\section{miRNAs as novel diagnostic and prognostic biomarkers in CCA}

The study by Meng et al. ${ }^{[19]}$ was the first to hint at the potential of miRNAs as biomarkers. It was found that miR-21 and miR-200b expression levels were predictors of gemcitabine resistance.

By sequencing and comparing the small RNA libraries of two CCA cell lines to one of a normal biliary epithelial line, Kawahigashi et $a l^{[120]}$ identified and confirmed miR-22, miR-125a, miR-127, miR-199a/a0, miR-214, miR-376a and miR-424 as specifically expressed in normal biliary epithelial cells, but down-regulated in CCA cell lines, suggesting their use as biomarkers for diagnosis. Chen et al. $^{[121]}$ took the approach of using miRNA sensor constructs to compare spatiotemporal activity of six miRNAs (miR-21, miR-200a, miR-200b, miR-146a, miR-155 and miR-221) in primary tissue blocks of CCA and normal control tissue grown from three patients using adeno-associated viral infections. They were unable to identify a definitive pattern between activity of each miRNA and presence of CCA over the entire time frame but when focusing on $24 \mathrm{~h}$ post-infection the miRNA profiles, displayed significant differences between CCA and control as well as between patients, suggesting these miRNAs play an active role in CCA. Karakatsanis et $a l^{[122]}$ evaluated the expression levels of several miRNA species in intrahepatic cholangiocellular carcinoma and their prognostic significance. Although miR-21, miR-31, and miR-223 were found to be up-regulated and miR-122, miR-145, miR-200c, miR-221, and miR-222 to be down-regulated, the group was unable to find any correlation with clinical or pathological features. McNally et $a l^{[123]}$ tried to investigate the predictive role of miRNAs on survival in resected CCAs and found 2 of 43 miRNA species evaluated to have the best correlation with survival. Up-regulation of miR-151-3p (41.5 months vs. 12.3 months) correlated better than down-regulation of miR-126 (21.9 months vs. 15.1 months). However, concomitant dysregulation of both showed the best overall correlation with survival (58.7 months vs. 15.1 months).

In a novel approach using bile, Li et al. ${ }^{[117]}$ were able to demonstrate the presence of miRNAs in extracellular vesicles in bile and analyzed the miRNA expression of 74 different species that could be reliably amplified. By using a multivariate organization of the combinatorial 
alterations, they were able to establish a miRNA-based panel of five different miRNA species that were able to distinguish CCA from primary sclerosing cholangitis or other biliary obstructions. This may offer an original way to make an early diagnosis of CCA.

\section{Clinical application of miRNAs in CCA}

Meng et al. ${ }^{[119]}$ provided the first evidence for the involvement of miRNAs, as well as its first therapeutic use in CCA. When they compared the miRNA expression patterns between malignant and non-malignant human cholangiocytes, miR-21, miR-141 and miR-200b were highly overexpressed in malignant cells and inhibition of miR-21 and miR-200b sensitized cells to gemcitabine. Treatment of xenografts with gemcitabine changed several miRNA expression levels and modulated phosphatase and tensin homolog-dependent PI3 kinase signaling. Okamoto et al. ${ }^{[124]}$ sought to investigate the role of miRNAs in chemoresistance and compared miRNA profiles of two CCA cell lines distinguished by gemcitabine resistance. They identified miR-29B, miR-205 and miR-221 whose ectopic overexpression could restore gemcitabine sensitivity in the resistant cell line. They showed that knockdown of two predicted targets, PIK3R1 (miR-29b and miR-221 target) and MMP-2 (miR-29b target only), via small interfering RNA conferred the same level of gemcitabine to the resistant cell line. They showed that miR-125a-5p was up-regulated in the resistant cell line and that inhibition of miR-125a-5p inhibited cell proliferation in that cell line independent of chemoresistance.

\section{Pancreatic Cancer}

Pancreatic ductal adenocarcinoma (PDAC) is a lethal malignancy with a poor prognosis due to advanced stage disease at initial diagnosis, frequent recurrence, and the absence of treatment strategies that specifically and effectively target these tumors. ${ }^{[125]}$ Only $15 \%$ of PDAC patients are candidates for surgical resection at the time of diagnosis. ${ }^{[126]}$ Chemotherapy is considered to be the main treatment option for unresectable cases, while chemoradiotherapy may improve the survival and quality of life. ${ }^{[127,128]}$ However, PDAC is still extremely resistant to the currently available regimens. Exploring miRNAs as therapeutic targets and biomarkers for the diagnosis and prognosis of PDAC is of interest. ${ }^{[129-131]}$

\section{miRNAs as novel diagnostic and prognostic biomarkers in pancreatic cancer}

Kong et al. ${ }^{[132]}$ found that three serum miRNAs, including miR-196a, were differentially expressed in PDAC compared with control groups. Another investigation by Wang et al. showed that the expression levels of four miRNAs in plasma (miR-21, miR-210, miR-155 and miR-196a) were significantly higher in patients with PDAC. ${ }^{[133]}$ Li et al. ${ }^{[134]}$ measured 735 circulating miRNAs in PDAC cases, and controls sera and miR-1290 were found to show the best diagnostic performance. Kawaguchi et al. ${ }^{[135]}$ found that plasma miR-221 concentrations were significantly higher in PDAC patients than those with benign pancreatic tumors and controls. In recent studies, miRNAs were also found to be useful as diagnostic markers for precursor lesions of PDAC. Caponi et al. ${ }^{[136]}$ found that miR-21 and miR-155 were up-regulated in invasive intraductal papillary mucinous neoplasms (IPMNs) compared with non-invasive IPMNs. Further multivariate analyses showed that high miR-21 expression emerged as an independent prognostic biomarker in invasive IPMNs with a poor survival. Lubezky et al. ${ }^{[137]}$ also found miRNAs were useful in identifying IPMN with high risk for malignant transformation. The expression levels of 15 miRNAs, including miR-217, miR-216a, miR-21 and miR-155, were significantly different between two IPMN subgroups (low/ moderate-grade dysplastic IPMNs vs. high-grade dysplastic IPMN) and invasive cancer with IPMN. Pancreatic cysts are a group of lesions with heterogeneous malignant potential. Farrell et al. ${ }^{[138]}$ showed miR-21 and miR-221 in pancreatic cyst fluid was associated with invasive cancer.

With regard to survival, strong miR-21 expression was predictive of poorer outcomes compared with absent or faint/focal miR-21 expression in patients with node-negative PDAC. ${ }^{[139]}$ Jamieson et al. ${ }^{[140]}$ found that high expression of miR-21 and reduced expression of miR-34a were significantly associated with a poor OS in global miRNA microarray expression profiling. Frampton et $a .^{[141]}$ found that a high level of a combination of miR-21, miR-23a and miR-27a was associated with shorter survival times after surgical resection. While strong expression of miR-21 predicted limited survival in PDAC patients, high expression of miR-200c, a member of the miR-200 family, is a good prognostic sign. ${ }^{[142,143]}$ Elevated levels of miR-155, miR-203, miR-210 and miR-222 expression in PDCA were significantly associated with an increased risk of death compared to patients with reduced expression of these miRNAs. ${ }^{[144]} \mathrm{A}$ subgroup of six miRNAs (miR-452, miR-105, miR-127, miR-518a-2, miR-187 and miR-30a-3p) was found to identify long-term survivors with node-positive disease from those dying within 24 months. ${ }^{[145]}$ In addition, increased expression levels of miR-155, miR-203, miR-210 and miR-222 were found to be significantly associated with poorer survival. ${ }^{[144,146]}$ In some recent studies, reduced expressions of miR-218 ${ }^{[147]}$ and miR-130b $b^{[148]}$ in PDAC tissues were found to correlate with a poor prognosis.

\section{Clinical application of miRNAs in pancreatic cancer}

Some prognostic miRNAs also play a role in the efficacy of anticancer therapy, thus presenting themselves as new therapeutic possibilities. For instance, PDAC cells 
expressing elevated levels of miR-21 are chemoresistant to gemcitabine and reduce the efficiency of apoptosis induction. ${ }^{[148,149]}$ miRNAs can be targeted. For example, inhibition of mir-21 by its antagonist led to the cessation of tumor growth and induction of apoptosis in vitro and in vivo (animal experimental model). ${ }^{[150]}$ Another therapeutic option comes from a possibility-of-function recovery of miR-34a, a potent pro-apoptotic component involved in p53-mediated apoptosis. As shown by Ji et $a l .,^{[151]}$ restoration of $\mathrm{miR}-34 \mathrm{a}$ may substitute the function of inactivated TP53 gene. It has been shown that miR-10a promotes the metastatic behavior of the pancreatic cancer (PC) and that its expression is regulated by retinoids. ${ }^{[152]}$ The use of retinoic acid receptor antagonists inhibit miR-10a expression and stop metastasis of PDAC cells. ${ }^{[152]}$ In contrast, miR-146a suppresses invasion of PC cells. However, its expression is lowered in PC compared to normal pancreatic tissue. Finally, use of non-toxic natural compounds which increase expression of miR-146a is also considered to be a promising approach to block both invasion and metastases. ${ }^{[153]}$

\section{Perspective}

Many miRNAs can be used in the diagnosis of cancer, in determining the patient prognosis or as therapeutic targets. We must develop more stringent protocols for collecting and analyzing samples (to avoid variations in sample processing or histologic characterization) and to validate each finding in large independent cohorts. This approach will lead to the selection of the best candidate miRNAs for further study, the development of highly reproducible results, and reduction in inter-study discrepancies. New miRNAs are continuously being discovered, and profiling technologies are rapidly changing. Thus, creating a standardization process for integrating data will be challenging. Development of effective in vivo delivery systems is also required if miRNAs are to be used as therapeutics.

Although many additional studies must be performed, miRNAs appear to have many useful clinical applications for patients with GI cancers and other GI disorders. The GI community should look forward to these studies with great anticipation.

\section{Financial support and sponsorship}

Nil.

\section{Conflicts of interest}

There are no conflicts of interest.

\section{References}

1. Marusawa H, Jenkins BJ. Inflammation and gastrointestinal cancer: An overview. Cancer Lett 2014;345:153-6.

2. Gartel AL, Kandel ES. miRNAs: Little known mediators of oncogenesis. Semin Cancer Biol 2008;18:103-10.

3. Friedman RC, Farh KK, Burge CB, Bartel DP. Most mammalian mRNAs are conserved targets of microRNAs. Genome Res 2009;19:92-105.

4. Ambros V. The functions of animal microRNAs. Nature 2004;431:350-5.

5. Calin GA, Croce CM. MicroRNA signatures in human cancers. Nat Rev Cancer 2006;6:857-66.

6. Johnson CD, Esquela-Kerscher A, Stefani G, Byrom M, Kelnar K, Ovcharenko D, Wilson M, Wang X, Shelton J, Shingara J, Chin L, Brown D, Slack FJ. The let-7 microRNA represses cell proliferation pathways in human cells. Cancer Res 2007;67:7713-22.

7. Kent OA, Mendell JT. A small piece in the cancer puzzle: MicroRNAs as tumor suppressors and oncogenes. Oncogene 2006;25:6188-96

8. Fassan M, Croce CM, Rugge M. miRNAs in precancerous lesions of the gastrointestinal tract. World $J$ Gastroenterol 2011;17:5231-9.

9. Song $\mathrm{B}, \mathrm{Ju} \mathrm{J}$. Impact of miRNAs in gastrointestinal cancer diagnosis and prognosis. Expert Rev Mol Med 2010;12:e33.

10. Boni V, Bandres E, Zarate R, Colucci G, Maiello E, Garcia-Foncillas J. MicroRNAs as a new potential therapeutic opportunity in gastrointestinal cancer. Oncology 2009;77 Suppl 1:75-89.

11. Vicentini C, Fassan M, D’Angelo E, Corbo V, Silvestris N, Nuovo GJ, Scarpa A. Clinical application of microRNA testing in neuroendocrine tumors of the gastrointestinal tract. Molecules 2014;19:2458-68.

12. Macha MA, Seshacharyulu P, Krishn SR, Pai P, Rachagani S, Jain M, Batra SK. MicroRNAs (miRNAs) as biomarker(s) for prognosis and diagnosis of gastrointestinal (GI) cancers. Curr Pharm Des 2014;20:5287-97.

13. Parkin DM, Bray F, Ferlay J, Pisani P. Global cancer statistics, 2002. CA Cancer J Clin 2005;55:74-108.

14. Enzinger PC, Mayer RJ. Esophageal cancer. $N$ Engl J Med 2003;349:2241-52.

15. He B, Yin B, Wang B, Xia Z, Chen C, Tang J. MicroRNAs in esophageal cancer (review). Mol Med Rep 2012;6:459-65.

16. Guo Y, Chen Z, Zhang L, Zhou F, Shi S, Feng X, Li B, Meng X, Ma X, Luo M, Shao K, Li N, Qiu B, Mitchelson K, Cheng J, He J. Distinctive microRNA profiles relating to patient survival in esophageal squamous cell carcinoma. Cancer Res 2008;68:26-33.

17. Feber A, Xi L, Luketich JD, Pennathur A, Landreneau RJ, $\mathrm{Wu}$ M, Swanson SJ, Godfrey TE, Litle VR. MicroRNA expression profiles of esophageal cancer. $J$ Thorac Cardiovasc Surg 2008;135:255-60.

18. Mathe EA, Nguyen GH, Bowman ED, Zhao Y, Budhu A, Schetter AJ, Braun R, Reimers M, Kumamoto K, Hughes D, Altorki NK, Casson AG, Liu CG, Wang XW, Yanaihara N, Hagiwara N, Dannenberg AJ, Miyashita M, Croce CM, Harris CC. MicroRNA expression in squamous cell carcinoma and adenocarcinoma of the esophagus: Associations with survival. Clin Cancer Res 2009;15:6192-200.

19. Kan T, Meltzer SJ. MicroRNAs in Barrett's esophagus and esophageal adenocarcinoma. Curr Opin Pharmacol 2009;9:727-32.

20. Maru DM, Singh RR, Hannah C, Albarracin CT, Li YX, Abraham R, Romans AM, Yao H, Luthra MG, Anandasabapathy S, Swisher SG, Hofstetter WL, Rashid A, Luthra R. MicroRNA-196a is a potential marker of progression during Barrett's metaplasia-dysplasia-invasive adenocarcinoma sequence in esophagus. Am J Pathol 2009;174:1940-8.

21. Ogawa R, Ishiguro H, Kuwabara Y, Kimura M, Mitsui A, Katada T, Harata K, Tanaka T, Fujii Y. Expression profiling of micro-RNAs in human esophageal squamous cell carcinoma 
using RT-PCR. Med Mol Morphol 2009;42:102-9.

22. Zhang T, Zhao D, Wang Q, Yu X, Cui Y, Guo L, Lu SH. MicroRNA-1322 regulates ECRG2 allele specifically and acts as a potential biomarker in patients with esophageal squamous cell carcinoma. Mol Carcinog 2013;52:581-90.

23. Lin RJ, Xiao DW, Liao LD, Chen T, Xie ZF, Huang WZ, Wang WS, Jiang TF, Wu BL, Li EM, Xu LY. MiR-142-3p as a potential prognostic biomarker for esophageal squamous cell carcinoma. J Surg Oncol 2012;105:175-82.

24. Leidner RS, Ravi L, Leahy P, Chen Y, Bednarchik B, Streppel M, Canto M, Wang JS, Maitra A, Willis J, Markowitz SD, Barnholtz-Sloan J, Adams MD, Chak A, Guda K. The microRNAs, MiR-31 and MiR-375, as candidate markers in Barrett's esophageal carcinogenesis. Genes Chromosomes Cancer 2012;51:473-9.

25. Hu Y, Correa AM, Hoque A, Guan B, Ye F, Huang J, Swisher SG, Wu TT, Ajani JA, Xu XC. Prognostic significance of differentially expressed miRNAs in esophageal cancer. Int $J$ Cancer 2011;128:132-43.

26. Komatsu S, Ichikawa D, Takeshita H, Tsujiura M, Morimura R, Nagata H, Kosuga T, litaka D, Konishi H, Shiozaki A, Fujiwara H, Okamoto K, Otsuji E. Circulating microRNAs in plasma of patients with oesophageal squamous cell carcinoma. Br J Cancer 2011;105:104-11.

27. Zhang C, Wang C, Chen X, Yang C, Li K, Wang J, Dai J, Hu Z, Zhou X, Chen L, Zhang Y, Li Y, Qiu H, Xing J, Liang Z, Ren B, Yang C, Zen K, Zhang CY. Expression profile of microRNAs in serum: a fingerprint for esophageal squamous cell carcinoma. Clin Chem 2010;56:1871-9.

28. Zhang T, Wang Q, Zhao D, Cui Y, Cao B, Guo L, Lu SH. The oncogenetic role of microRNA-31 as a potential biomarker in oesophageal squamous cell carcinoma. Clin Sci (Lond) 2011;121:437-47.

29. Hummel R, Wang T, Watson DI, Michael MZ, Van der Hoek M, Haier J, Hussey DJ. Chemotherapy-induced modification of microRNA expression in esophageal cancer. Oncol Rep 2011;26:1011-7.

30. Imanaka Y, Tsuchiya S, Sato F, Shimada Y, Shimizu K, Tsujimoto G. MicroRNA-141 confers resistance to cisplatin-induced apoptosis by targeting YAP1 in human esophageal squamous cell carcinoma. $J$ Hum Genet 2011;56:270-6.

31. Zhang H, Li M, Han Y, Hong L, Gong T, Sun L, Zheng X. Down-regulation of miR-27a might reverse multidrug resistance of esophageal squamous cell carcinoma. Dig Dis Sci 2010;55:2545-51.

32. Hong L, Han Y, Zhang H, Li M, Gong T, Sun L, Wu K, Zhao Q, Fan D. The prognostic and chemotherapeutic value of miR-296 in esophageal squamous cell carcinoma. Ann Surg 2010;251:1056-63.

33. Hamano R, Miyata H, Yamasaki M, Kurokawa Y, Hara J, Moon JH, Nakajima K, Takiguchi S, Fujiwara Y, Mori M, Doki Y. Overexpression of miR-200c induces chemoresistance in esophageal cancers mediated through activation of the Akt signaling pathway. Clin Cancer Res 2011;17:3029-38.

34. Hummel R, Watson DI, Smith C, Kist J, Michael MZ, Haier J, Hussey DJ. Mir-148a improves response to chemotherapy in sensitive and resistant oesophageal adenocarcinoma and squamous cell carcinoma cells. J Gastrointest Surg 2011;15:429-38.

35. Wu Y, Xiao Y, Ding X, Zhuo Y, Ren P, Zhou C, Zhou J. A miR-200b/200c/429-binding site polymorphism in the 3' untranslated region of the AP-2alpha gene is associated with cisplatin resistance. PLoS One 2011;6:e29043.

36. Ferlay J, Shin HR, Bray F, Forman D, Mathers C, Parkin DM.
Estimates of worldwide burden of cancer in 2008: GLOBOCAN 2008. Int J Cancer 2010;127:2893-917.

37. Coburn NG. Lymph nodes and gastric cancer. J Surg Oncol 2009;99:199-206.

38. Wu WK, Lee CW, Cho CH, Fan D, Wu K, Yu J, Sung JJ. MicroRNA dysregulation in gastric cancer: A new player enters the game. Oncogene 2010;29:5761-71.

39. Song S, Ajani JA. The role of microRNAs in cancers of the upper gastrointestinal tract. Nat Rev Gastroenterol Hepatol 2013;10:109-18.

40. Matuszcak C, Haier J, Hummel R, Lindner K. MicroRNAs: Promising chemoresistance biomarkers in gastric cancer with diagnostic and therapeutic potential. World $J$ Gastroenterol 2014;20:13658-66.

41. Song MY, Pan KF, Su HJ, Zhang L, Ma JL, Li JY, Yuasa Y, Kang D, Kim YS, You WC. Identification of serum microRNAs as novel non-invasive biomarkers for early detection of gastric cancer. PLoS One 2012;7:e33608.

42. Konishi H, Ichikawa D, Komatsu S, Shiozaki A, Tsujiura M, Takeshita H, Morimura R, Nagata H, Arita T, Kawaguchi T, Hirashima S, Fujiwara H, Okamoto K, Otsuji E. Detection of gastric cancer-associated microRNAs on microRNA microarray comparing pre- and post-operative plasma. $\mathrm{Br} J$ Cancer 2012;106:740-7.

43. Liu H, Zhu L, Liu B, Yang L, Meng X, Zhang W, Ma Y, Xiao H. Genome-wide microRNA profiles identify miR-378 as a serum biomarker for early detection of gastric cancer. Cancer Lett 2012;316:196-203.

44. Liu R, Zhang C, Hu Z, Li G, Wang C, Yang C, Huang D, Chen X, Zhang H, Zhuang R, Deng T, Liu H, Yin J, Wang S, Zen K, Ba Y, Zhang CY. A five-microRNA signature identified from genome-wide serum microRNA expression profiling serves as a fingerprint for gastric cancer diagnosis. Eur $J$ Cancer 2011;47:784-91.

45. Tsujiura M, Ichikawa D, Komatsu S, Shiozaki A, Takeshita H, Kosuga T, Konishi H, Morimura R, Deguchi K, Fujiwara H, Okamoto K, Otsuji E. Circulating microRNAs in plasma of patients with gastric cancers. Br J Cancer 2010;102:1174-9.

46. Zhou H, Guo JM, Lou YR, Zhang XJ, Zhong FD, Jiang Z, Cheng J, Xiao BX. Detection of circulating tumor cells in peripheral blood from patients with gastric cancer using microRNA as a marker. J Mol Med (Berl) 2010;88:709-17.

47. Li X, Zhang Y, Zhang Y, Ding J, Wu K, Fan D. Survival prediction of gastric cancer by a seven-microRNA signature. Gut 2010;59:579-85.

48. Katada T, Ishiguro H, Kuwabara Y, Kimura M, Mitui A, Mori Y, Ogawa R, Harata K, Fujii Y. microRNA expression profile in undifferentiated gastric cancer. Int J Oncol 2009;34:537-42.

49. Chen L, Jiang M, Yuan W, Tang H. Prognostic value of miR-93 overexpression in resectable gastric adenocarcinomas. Acta Gastroenterol Belg 2012;75:22-7.

50. Bandres E, Bitarte N, Arias F, Agorreta J, Fortes P, Agirre X, Zarate R, Diaz-Gonzalez JA, Ramirez N, Sola JJ, Jimenez P, Rodriguez J, Garcia-Foncillas J. microRNA-451 regulates macrophage migration inhibitory factor production and proliferation of gastrointestinal cancer cells. Clin Cancer Res 2009; 15:2281-90.

51. Tie J, Pan Y, Zhao L, Wu K, Liu J, Sun S, Guo X, Wang B, Gang Y, Zhang Y, Li Q, Qiao T, Zhao Q, Nie Y, Fan D. MiR-218 inhibits invasion and metastasis of gastric cancer by targeting the Robo1 receptor. PLoS Genet 2010;6:e1000879.

52. Ueda T, Volinia S, Okumura H, Shimizu M, Taccioli C, Rossi S, Alder H, Liu CG, Oue N, Yasui W, Yoshida K, Sasaki H, Nomura S, Seto Y, Kaminishi M, Calin GA, Croce CM. Relation between microRNA expression and 
progression and prognosis of gastric cancer: a microRNA expression analysis. Lancet Oncol 2010;11:136-46.

53. Wang M, Gu H, Wang S, Qian H, Zhu W, Zhang L, Zhao C, Tao Y, Xu W. Circulating miR-17-5p and miR-20a: molecular markers for gastric cancer. Mol Med Rep 2012;5:1514-20.

54. Yang Q, Jie Z, Cao H, Greenlee AR, Yang C, Zou F, Jiang Y. Low-level expression of let-7a in gastric cancer and its involvement in tumorigenesis by targeting RAB40C. Carcinogenesis 2011;32:713-22.

55. Kim CH, Kim HK, Rettig RL, Kim J, Lee ET, Aprelikova O, Choi IJ, Munroe DJ, Green JE. miRNA signature associated with outcome of gastric cancer patients following chemotherapy. BMC Med Genomics 2011;4:79.

56. Chen L, Yang Q, Kong WQ, Liu T, Liu M, Li X, Tang H. MicroRNA-181b targets cAMP responsive element binding protein 1 in gastric adenocarcinomas. IUBMB Life 2012;64:628-35

57. Hashiguchi Y, Nishida N, Mimori K, Sudo T, Tanaka F, Shibata K, Ishii H, Mochizuki H, Hase K, Doki Y, Mori M. Down-regulation of miR-125a-3p in human gastric cancer and its clinicopathological significance. Int $J$ Oncol 2012;40:1477-82.

58. Zheng B, Liang L, Huang S, Zha R, Liu L, Jia D, Tian Q, Wang Q, Wang C, Long Z, Zhou Y, Cao X, Du C, Shi Y, He X. MicroRNA-409 suppresses tumour cell invasion and metastasis by directly targeting radixin in gastric cancers. Oncogene 2012;31:4509-16.

59. Yang SM, Huang C, Li XF, Yu MZ, He Y, Li J. miR-21 confers cisplatin resistance in gastric cancer cells by regulating PTEN. Toxicology 2013;306:162-8.

60. Deng H, Guo Y, Song H, Xiao B, Sun W, Liu Z, Yu X, Xia T, Cui L, Guo J. MicroRNA-195 and microRNA-378 mediate tumor growth suppression by epigenetical regulation in gastric cancer. Gene 2013;518:351-9.

61. Shang Y, Zhang Z, Liu Z, Feng B, Ren G, Li K, Zhou L, Sun Y, Li M, Zhou J, An Y, Wu K, Nie Y, Fan D. miR-508-5p regulates multidrug resistance of gastric cancer by targeting ABCB1 and ZNRD1. Oncogene 2014;33:3267-76.

62. Hu J, Fang Y, Cao Y, Qin R, Chen Q. miR-449a Regulates proliferation and chemosensitivity to cisplatin by targeting cyclin D1 and BCL2 in SGC7901 cells. Dig Dis Sci 2014;59:336-45.

63. Zhao X, Yang L, Hu J. Down-regulation of miR-27a might inhibit proliferation and drug resistance of gastric cancer cells. $J$ Exp Clin Cancer Res 2011;30:55.

64. Lieberman D. Progress and challenges in colorectal cancer screening and surveillance. Gastroenterology 2010;138:2115-26.

65. Ng EK, Chong WW, Jin H, Lam EK, Shin VY, Yu J, Poon TC, $\mathrm{Ng}$ SS, Sung JJ. Differential expression of microRNAs in plasma of patients with colorectal cancer: a potential marker for colorectal cancer screening. Gut 2009;58:1375-81.

66. Huang Z, Huang D, Ni S, Peng Z, Sheng W, Du X. Plasma microRNAs are promising novel biomarkers for early detection of colorectal cancer. Int J Cancer 2010;127:118-26.

67. Cheng H, Zhang L, Cogdell DE, Zheng H, Schetter AJ, Nykter M, Harris CC, Chen K, Hamilton SR, Zhang W. Circulating plasma MiR-141 is a novel biomarker for metastatic colon cancer and predicts poor prognosis. PLoS One 2011;6:e17745.

68. Link A, Balaguer F, Shen Y, Nagasaka T, Lozano JJ, Boland CR, Goel A. Fecal MicroRNAs as novel biomarkers for colon cancer screening. Cancer Epidemiol Biomarkers Prev 2010;19:1766-74.
69. Koga Y, Yasunaga M, Takahashi A, Kuroda J, Moriya Y, Akasu T, Fujita S, Yamamoto S, Baba H, Matsumura Y. MicroRNA expression profiling of exfoliated colonocytes isolated from feces for colorectal cancer screening. Cancer Prev Res (Phila) 2010;3:1435-42.

70. Kalimutho M, Di Cecilia S, Del Vecchio Blanco G, Roviello F, Sileri P, Cretella M, Formosa A, Corso G, Marrelli D, Pallone F, Federici G, Bernardini S. Epigenetically silenced $\mathrm{miR}-34 \mathrm{~b} / \mathrm{c}$ as a novel faecal-based screening marker for colorectal cancer. Br J Cancer 2011;104:1770-8.

71. Schetter AJ, Leung SY, Sohn JJ, Zanetti KA, Bowman ED, Yanaihara N, Yuen ST, Chan TL, Kwong DL, Au GK, Liu CG, Calin GA, Croce CM, Harris CC. MicroRNA expression profiles associated with prognosis and therapeutic outcome in colon adenocarcinoma. JAMA 2008;299:425-36.

72. Shibuya H, Iinuma H, Shimada R, Horiuchi A, Watanabe T. Clinicopathological and prognostic value of microRNA-21 and microRNA-155 in colorectal cancer. Oncology 2010;79:313-20.

73. Kulda V, Pesta M, Topolcan O, Liska V, Treska V, Sutnar A, Rupert K, Ludvikova M, Babuska V, Holubec L Jr, Cerny R. Relevance of miR-21 and miR-143 expression in tissue samples of colorectal carcinoma and its liver metastases. Cancer Genet Cytogenet 2010;200:154-60.

74. Nielsen BS, Jorgensen S, Fog JU, Sokilde R, Christensen IJ, Hansen U, Brunner N, Baker A, Moller S, Nielsen HJ. High levels of microRNA-21 in the stroma of colorectal cancers predict short disease-free survival in stage II colon cancer patients. Clin Exp Metastasis 2011;28:27-38.

75. Diaz R, Silva J, Garcia JM, Lorenzo Y, Garcia V, Pena C, Rodriguez R, Munoz C, Garcia F, Bonilla F, Dominguez G. Deregulated expression of miR-106a predicts survival in human colon cancer patients. Genes Chromosomes Cancer 2008;47:794-802.

76. Schepeler T, Reinert JT, Ostenfeld MS, Christensen LL, Silahtaroglu AN, Dyrskjot L, Wiuf C, Sorensen FJ, Kruhoffer M, Laurberg S, Kauppinen S, Orntoft TF, Andersen CL. Diagnostic and prognostic microRNAs in stage II colon cancer. Cancer Res 2008;68:6416-24.

77. Nishida N, Yokobori T, Mimori K, Sudo T, Tanaka F, Shibata K, Ishii H, Doki Y, Kuwano H, Mori M. MicroRNA miR-125b is a prognostic marker in human colorectal cancer. Int J Oncol 2011;38:1437-43.

78. Drebber U, Lay M, Wedemeyer I, Vallbohmer D, Bollschweiler E, Brabender J, Monig SP, Holscher AH, Dienes HP, Odenthal M. Altered levels of the onco-microRNA 21 and the tumor-supressor microRNAs 143 and 145 in advanced rectal cancer indicate successful neoadjuvant chemoradiotherapy. Int J Oncol 2011;39:409-15.

79. Akcakaya P, Ekelund S, Kolosenko I, Caramuta S, Ozata DM, Xie H, Lindforss U, Olivecrona H, Lui WO. miR-185 and miR-133b deregulation is associated with overall survival and metastasis in colorectal cancer. Int J Oncol 2011;39:311-8.

80. Karaayvaz M, Pal T, Song B, Zhang C, Georgakopoulos P, Mehmood S, Burke S, Shroyer K, Ju J. Prognostic significance of miR-215 in colon cancer. Clin Colorectal Cancer 2011;10:340-7.

81. Yu G, Tang JQ, Tian ML, Li H, Wang X, Wu T, Zhu J, Huang SJ, Wan YL. Prognostic values of the miR-17-92 cluster and its paralogs in colon cancer. J Surg Oncol 2012;106:232-7.

82. Faber C, Horst D, Hlubek F, Kirchner T. Overexpression of Dicer predicts poor survival in colorectal cancer. Eur J Cancer 2011;47:1414-9.

83. Valeri N, Gasparini P, Braconi C, Paone A, Lovat F, Fabbri M, 
Sumani KM, Alder H, Amadori D, Patel T, Nuovo GJ, Fishel R, Croce CM. MicroRNA-21 induces resistance to 5-fluorouracil by down-regulating human DNA MutS homolog 2 (hMSH2). Proc Natl Acad Sci U S A 2010;107:21098-103.

84. Rossi L, Bonmassar E, Faraoni I. Modification of miR gene expression pattern in human colon cancer cells following exposure to 5-fluorouracil in vitro. Pharmacol Res 2007;56:248-53.

85. Song B, Wang Y, Xi Y, Kudo K, Bruheim S, Botchkina GI, Gavin E, Wan Y, Formentini A, Kornmann M, Fodstad O, $\mathrm{Ju} \mathrm{J}$. Mechanism of chemoresistance mediated by miR-140 in human osteosarcoma and colon cancer cells. Oncogene 2009;28:4065-74.

86. Song B, Wang Y, Titmus MA, Botchkina G, Formentini A, Kornmann M, Ju J. Molecular mechanism of chemoresistance by miR-215 in osteosarcoma and colon cancer cells. Mol Cancer 2010;9:96.

87. Mencia N, Selga E, Noe V, Ciudad CJ. Underexpression of miR-224 in methotrexate resistant human colon cancer cells. Biochem Pharmacol 2011;82:1572-82.

88. Chai H, Liu M, Tian R, Li X, Tang H. miR-20a targets BNIP2 and contributes chemotherapeutic resistance in colorectal adenocarcinoma SW480 and SW620 cell lines. Acta Biochim Biophys Sin (Shanghai) 2011;43:217-25.

89. Ibrahim AF, Weirauch U, Thomas M, Grunweller A, Hartmann RK, Aigner A. MicroRNA replacement therapy for miR-145 and miR-33a is efficacious in a model of colon carcinoma. Cancer Res 2011;71:5214-24.

90. Yang JD, Roberts LR. Epidemiology and management of hepatocellular carcinoma. Infect Dis Clin North Am 2010;24:899-919, viii.

91. Bruix J, Sherman M. Management of hepatocellular carcinoma. Hepatology 2005;42:1208-36.

92. Siegel R, Naishadham D, Jemal A. Cancer statistics, 2012. CA Cancer J Clin 2012;62:10-29.

93. Huang XB, Li J, Zheng L, Zuo GH, Han KQ, Li HY, Liang P. Bioinformatics analysis reveals potential candidate drugs for HCC. Pathol Oncol Res 2013;19:251-8.

94. El-Serag HB. Hepatocellular carcinoma and hepatitis C in the United States. Hepatology 2002;36:S74-83.

95. Lin CL, Kao JH. Hepatitis B viral factors and clinical outcomes of chronic hepatitis B. J Biomed Sci 2008;15:137-45.

96. Zhu Z, Zhang X, Wang G, Zheng H. Role of microRNAs in hepatocellular carcinoma. Hepat Mon 2014;14:e18672.

97. Otsuka M, Kishikawa T, Yoshikawa T, Ohno M, Takata A, Shibata C, Koike K. The role of microRNAs in hepatocarcinogenesis: current knowledge and future prospects. J Gastroenterol 2014;49:173-84.

98. Hung $\mathrm{CH}$, Chiu $\mathrm{YC}$, Chen $\mathrm{CH}, \mathrm{Hu}$ TH. MicroRNAs in hepatocellular carcinoma: Carcinogenesis, progression, and therapeutic target. Biomed Res Int 2014;2014:486407.

99. Petrelli A, Perra A, Cora D, Sulas P, Menegon S, Manca C, Migliore C, Kowalik MA, Ledda-Columbano GM, Giordano S, Columbano A. MicroRNA/gene profiling unveils early molecular changes and nuclear factor erythroid related factor 2 (NRF2) activation in a rat model recapitulating human hepatocellular carcinoma (HCC). Hepatology 2014;59:228-41.

100. Xu J, Wu C, Che X, Wang L, Yu D, Zhang T, Huang L, Li H, Tan W, Wang C, Lin D. Circulating microRNAs, miR-21, miR-122, and miR-223, in patients with hepatocellular carcinoma or chronic hepatitis. Mol Carcinog 2011;50:136-42.

101. Li J, Wang Y, Yu W, Chen J, Luo J. Expression of serum miR-221 in human hepatocellular carcinoma and its prognostic significance. Biochem Biophys Res Commun 2011;406:70-3.
102. Tomimaru Y, Eguchi H, Nagano H, Wada H, Kobayashi S, Marubashi S, Tanemura M, Tomokuni A, Takemasa I, Umeshita K, Kanto T, Doki Y, Mori M. Circulating microRNA-2 1 as a novel biomarker for hepatocellular carcinoma. J Hepatol 2012;56:167-75.

103. Li LM, Hu ZB, Zhou ZX, Chen X, Liu FY, Zhang JF, Shen HB, Zhang CY, Zen K. Serum microRNA profiles serve as novel biomarkers for HBV infection and diagnosis of HBV-positive hepatocarcinoma. Cancer Res 2010;70:9798-807.

104. Liu AM, Yao TJ, Wang W, Wong KF, Lee NP, Fan ST, Poon RT, Gao C, Luk JM. Circulating miR-15b and miR-130b in serum as potential markers for detecting hepatocellular carcinoma: A retrospective cohort study. BMJ Open 2012;2:e000825.

105. Hou W, Bonkovsky HL. Non-coding RNAs in hepatitis C-induced hepatocellular carcinoma: dysregulation and implications for early detection, diagnosis and therapy. World J Gastroenterol 2013;19:7836-45.

106. Qu KZ, Zhang K, Li H, Afdhal NH, Albitar M. Circulating microRNAs as biomarkers for hepatocellular carcinoma. J Clin Gastroenterol 2011;45:355-60.

107. Hu QY, Jiang H, Su J, Jia YQ. MicroRNAs as biomarkers for hepatocellular carcinoma: a diagnostic meta-analysis. Clin Lab 2013;59:1113-20

108. Wang XW, Heegaard NH, Orum H. MicroRNAs in liver disease. Gastroenterology 2012;142:1431-43.

109. Janssen HL, Reesink HW, Lawitz EJ, Zeuzem S, Rodriguez-Torres M, Patel K, van der Meer AJ, Patick AK, Chen A, Zhou Y, Persson R, King BD, Kauppinen S, Levin AA, Hodges MR. Treatment of HCV infection by targeting microRNA. $N$ Engl J Med 2013;368:1685-94.

110. Jopling CL, Yi M, Lancaster AM, Lemon SM, Sarnow P. Modulation of hepatitis C virus RNA abundance by a liver-specific MicroRNA. Science 2005;309:1577-81.

111. Fukuhara T, Matsuura Y. Role of miR-122 and lipid metabolism in HCV infection. $J$ Gastroenterol 2013;48:169-76.

112. Bouchie A. First microRNA mimic enters clinic. Nat Biotechnol 2013;31:577.

113. de Groen PC, Gores GJ, LaRusso NF, Gunderson LL, Nagorney DM. Biliary tract cancers. $N$ Engl $J$ Med 1999;341:1368-78.

114. Razumilava N, Gores GJ. Cholangiocarcinoma. Lancet 2014;383:2168-79.

115. Blechacz B, Gores GJ. Cholangiocarcinoma: advances in pathogenesis, diagnosis, and treatment. Hepatology 2008;48:308-21.

116. Olaru AV, Ghiaur G, Yamanaka S, Luvsanjav D, An F, Popescu I, Alexandrescu S, Allen S, Pawlik TM, Torbenson M, Georgiades C, Roberts LR, Gores GJ, Ferguson-Smith A, Almeida MI, Calin GA, Mezey E, Selaru FM. MicroRNA down-regulated in human cholangiocarcinoma control cell cycle through multiple targets involved in the G1/S checkpoint. Hepatology 2011;54:2089-98.

117. Li L, Masica D, Ishida M, Tomuleasa C, Umegaki S, Kalloo AN, Georgiades C, Singh VK, Khashab M, Amateau S, Li Z, Okolo P, Lennon AM, Saxena P, Geschwind JF, Schlachter T, Hong $\mathrm{K}$, Pawlik TM, Canto $\mathrm{M}$, Law J, Sharaiha R, Weiss CR, Thuluvath P, Goggins M, Shin EJ, Peng H, Kumbhari V, Hutfless S, Zhou L, Mezey E, Meltzer SJ, Karchin R, Selaru FM. Human bile contains microRNA-laden extracellular vesicles that can be used for cholangiocarcinoma diagnosis. Hepatology 2014;60:896-907.

118. Piontek K, Selaru FM. MicroRNAs in the biology and diagnosis of cholangiocarcinoma. Semin Liver Dis 2015;35:55-62. 
119. Meng F, Henson R, Lang M, Wehbe H, Maheshwari S, Mendell JT, Jiang J, Schmittgen TD, Patel T. Involvement of human micro-RNA in growth and response to chemotherapy in human cholangiocarcinoma cell lines. Gastroenterology 2006;130:2113-29.

120. Kawahigashi Y, Mishima T, Mizuguchi Y, Arima Y, Yokomuro S, Kanda $\mathrm{T}$, Ishibashi $\mathrm{O}$, Yoshida $\mathrm{H}$, Tajiri T, Takizawa T. MicroRNA profiling of human intrahepatic cholangiocarcinoma cell lines reveals biliary epithelial cell-specific microRNAs. J Nippon Med Sch 2009;76:188-97.

121. Chen X, Chen J, Liu X, Guo Z, Sun X, Zhang J. The real-time dynamic monitoring of microRNA function in cholangiocarcinoma. PLoS One 2014;9:e99431.

122. Karakatsanis A, Papaconstantinou I, Gazouli M, Lyberopoulou A, Polymeneas G, Voros D. Expression of microRNAs, miR-21, miR-31, miR-122, miR-145, miR-146a, miR-200c, miR-221, miR-222, and miR-223 in patients with hepatocellular carcinoma or intrahepatic cholangiocarcinoma and its prognostic significance. Mol Carcinog 2013;52:297-303.

123. McNally ME, Collins A, Wojcik SE, Liu J, Henry JC, Jiang J, Schmittgen T, Bloomston M. Concomitant dysregulation of microRNAs miR-151-3p and miR-126 correlates with improved survival in resected cholangiocarcinoma. HPB (Oxford) 2013;15:260-4.

124. Okamoto K, Miyoshi K, Murawaki Y. miR-29b, miR-205 and miR-221 enhance chemosensitivity to gemcitabine in $\mathrm{HuH} 28$ human cholangiocarcinoma cells. PLoS One 2013;8:e77623.

125. Kaur S, Kumar S, Momi N, Sasson AR, Batra SK. Mucins in pancreatic cancer and its microenvironment. Nat Rev Gastroenterol Hepatol 2013;10:607-20.

126. Camacho D, Reichenbach D, Duerr GD, Venema TL, Sweeney JF, Fisher WE. Value of laparoscopy in the staging of pancreatic cancer. JOP 2005;6:552-61.

127. Burris HA 3rd, Moore MJ, Andersen J, Green MR, Rothenberg ML, Modiano MR, Cripps MC, Portenoy RK, Storniolo AM, Tarassoff P, Nelson R, Dorr FA, Stephens CD, Von Hoff DD. Improvements in survival and clinical benefit with gemcitabine as first-line therapy for patients with advanced pancreas cancer: A randomized trial. J Clin Oncol 1997; 15:2403-13.

128. Cardenes HR, Moore AM, Johnson CS, Yu M, Helft P, Chiorean EG, Vinson J, Howard TJ, Stephens AW, Tai DF, Loehrer PJ Sr. A phase II study of gemcitabine in combination with radiation therapy in patients with localized, unresectable, pancreatic cancer: A Hoosier Oncology Group study. Am J Clin Oncol 2011;34:460-5.

129. Tang YT, Xu XH, Yang XD, Hao J, Cao H, Zhu W, Zhang SY, Cao JP. Role of non-coding RNAs in pancreatic cancer: the bane of the microworld. World $J$ Gastroenterol 2014;20:9405-17.

130. Sun T, Kong X, Du Y, Li Z. Aberrant microRNAs in pancreatic cancer: Researches and clinical implications. Gastroenterol Res Pract 2014;2014:386561.

131. Halkova T, Cuperkova R, Minarik M, Benesova L. MicroRNAs in pancreatic cancer: involvement in carcinogenesis and potential use for diagnosis and prognosis. Gastroenterol Res Pract 2015;2015:892903.

132. Kong X, Du Y, Wang G, Gao J, Gong Y, Li L, Zhang Z, Zhu J, Jing Q, Qin Y, Li Z. Detection of differentially expressed microRNAs in serum of pancreatic ductal adenocarcinoma patients: miR-196a could be a potential marker for poor prognosis. Dig Dis Sci 2011;56:602-9.

133. Wang J, Chen J, Chang P, LeBlanc A, Li D, Abbruzzesse JL,
Frazier ML, Killary AM, Sen S. MicroRNAs in plasma of pancreatic ductal adenocarcinoma patients as novel blood-based biomarkers of disease. Cancer Prev Res (Phila) 2009;2:807-13.

134. Li A, Yu J, Kim H, Wolfgang CL, Canto MI, Hruban RH, Goggins M. Serum miR-1290 as a marker of pancreatic cancer-response. Clin Cancer Res 2013;19:5252-3.

135. Kawaguchi T, Komatsu S, Ichikawa D, Morimura R, Tsujiura M, Konishi H, Takeshita H, Nagata H, Arita T, Hirajima S, Shiozaki A, Ikoma H, Okamoto K, Ochiai T, Taniguchi H, Otsuji E. Clinical impact of circulating miR-221 in plasma of patients with pancreatic cancer. $\mathrm{Br} J$ Cancer 2013;108:361-9.

136. Caponi S, Funel N, Frampton AE, Mosca F, Santarpia L, Van der Velde AG, Jiao LR, De Lio N, Falcone A, Kazemier G, Meijer GA, Verheul HM, Vasile E, Peters GJ, Boggi U, Giovannetti E. The good, the bad and the ugly: a tale of miR-101, miR-21 and miR-155 in pancreatic intraductal papillary mucinous neoplasms. Ann Oncol 2013;24:734-41.

137. Lubezky N, Loewenstein S, Ben-Haim M, Brazowski E, Marmor S, Pasmanik-Chor M, Oron-Karni V, Rechavi G, Klausner JM, Lahat G. MicroRNA expression signatures in intraductal papillary mucinous neoplasm of the pancreas. Surgery 2013;153:663-72.

138. Farrell JJ, Toste P, Wu N, Li L, Wong J, Malkhassian D, Tran LM, Wu X, Li X, Dawson D, Wu H, Donahue TR. Endoscopically acquired pancreatic cyst fluid microRNA 21 and 221 are associated with invasive cancer. $\mathrm{Am} J$ Gastroenterol 2013;108:1352-9.

139. Dillhoff M, Liu J, Frankel W, Croce C, Bloomston M. MicroRNA-21 is overexpressed in pancreatic cancer and a potential predictor of survival. J Gastrointest Surg 2008;12:2171-6.

140. Jamieson NB, Morran DC, Morton JP, Ali A, Dickson EJ, Carter CR, Sansom OJ, Evans TR, McKay CJ, Oien KA. MicroRNA molecular profiles associated with diagnosis, clinicopathologic criteria, and overall survival in patients with resectable pancreatic ductal adenocarcinoma. Clin Cancer Res 2012;18:534-45.

141. Frampton AE, Castellano L, Colombo T, Giovannetti E, Krell J, Jacob J, Pellegrino L, Roca-Alonso L, Funel N, Gall TM, De Giorgio A, Pinho FG, Fulci V, Britton DJ, Ahmad R, Habib NA, Coombes RC, Harding V, Knosel T, Stebbing J, Jiao LR. MicroRNAs cooperatively inhibit a network of tumor suppressor genes to promote pancreatic tumor growth and progression. Gastroenterology 2014;146:268-77.e18.

142. Yu J, Ohuchida K, Mizumoto K, Sato N, Kayashima T, Fujita H, Nakata K, Tanaka M. MicroRNA, hsa-miR-200c, is an independent prognostic factor in pancreatic cancer and its upregulation inhibits pancreatic cancer invasion but increases cell proliferation. Mol Cancer 2010;9:169.

143. Radhakrishnan P, Mohr AM, Grandgenett PM, Steele MM, Batra SK, Hollingsworth MA. MicroRNA-200c modulates the expression of MUC4 and MUC16 by directly targeting their coding sequences in human pancreatic cancer. PLoS One 2013;8:e73356.

144. Greither T, Grochola LF, Udelnow A, Lautenschlager C, Wurl P, Taubert H. Elevated expression of microRNAs 155, 203, 210 and 222 in pancreatic tumors is associated with poorer survival. Int $J$ Cancer 2010;126:73-80.

145. Bloomston M, Frankel WL, Petrocca F, Volinia S, Alder H, Hagan JP, Liu CG, Bhatt D, Taccioli C, Croce CM. MicroRNA expression patterns to differentiate pancreatic adenocarcinoma from normal pancreas and chronic pancreatitis. JAMA 2007;297:1901-8 
146. Lee C, He H, Jiang Y, Di Y, Yang F, Li J, Jin C, Fu D. Elevated expression of tumor miR-222 in pancreatic cancer is associated with Ki67 and poor prognosis. Med Oncol 2013;30:700.

147. Zhu Z, Xu Y, Du J, Tan J, Jiao H. Expression of microRNA-218 in human pancreatic ductal adenocarcinoma and its correlation with tumor progression and patient survival. J Surg Oncol 2014;109:89-94.

148. Giovannetti E, Funel N, Peters GJ, Del Chiaro M, Erozenci LA, Vasile E, Leon LG, Pollina LE, Groen A, Falcone A, Danesi R, Campani D, Verheul HM, Boggi U. MicroRNA-21 in pancreatic cancer: Correlation with clinical outcome and pharmacologic aspects underlying its role in the modulation of gemcitabine activity. Cancer Res 2010;70:4528-38.

149. Hwang JH, Voortman J, Giovannetti E, Steinberg SM, Leon LG, Kim YT, Funel N, Park JK, Kim MA, Kang GH, Kim SW, Del Chiaro M, Peters GJ, Giaccone G. Identification of microRNA-21 as a biomarker for chemoresistance and clinical outcome following adjuvant therapy in resectable pancreatic cancer. PLoS One 2010;5:e10630.

150. Sicard F, Gayral M, Lulka H, Buscail L, Cordelier P. Targeting miR-21 for the therapy of pancreatic cancer. Mol Ther 2013;21:986-94.

151. Ji Q, Hao X, Zhang M, Tang W, Yang M, Li L, Xiang D, Desano JT, Bommer GT, Fan D, Fearon ER, Lawrence TS, $\mathrm{Xu}$ L. MicroRNA miR-34 inhibits human pancreatic cancer tumor-initiating cells. PLoS One 2009;4:e6816.

152. Weiss FU, Marques IJ, Woltering JM, Vlecken DH, Aghdassi A, Partecke LI, Heidecke CD, Lerch MM, Bagowski CP. Retinoic acid receptor antagonists inhibit miR-10a expression and block metastatic behavior of pancreatic cancer. Gastroenterology 2009;137:2136-45.e1-7.

153. Li Y, Vandenboom TG 2nd, Wang Z, Kong D, Ali S, Philip PA, Sarkar FH. miR-146a suppresses invasion of pancreatic cancer cells. Cancer Res 2010;70:1486-95. 